\title{
The incidence of earnings management on audit quality
}

\author{
Marta TACHE \\ Bucharest University of Economic Studies, Bucharest, Romania \\ tache.marta@yahoo.com
}

\begin{abstract}
The purpose of this article is to analyse the impact of earnings management on audit quality, taking into consideration the transparency of financial reporting under IFRS (International Financial Reporting Standards). The global reporting has undergone important changes in the last decade of time. IFRS represents a revolution concerning the accounting principles and these standards were created to aid the investors and the auditors with the globalisation. Although there is a replete foundation of rules, the high degree of competition has decreased the accuracy of financial reporting through different ways and consequently the level of audit quality. Earnings management has the root in the incentives for management taking into consideration the linkage between the values of entities, the reported earnings figures and the measure of discretionary (abnormal) accruals. The main purpose of the research is represented by the investigation of accuracy of financial reporting concerning the linkage between earnings management and audit quality. The in-depth acquaintance of these elements highlights the actual circumstances of institutional context related to IFRS and ISA framework. In the present survey, a sample of 14 countries, during 2010-2019 was analysed. The study involves a quantitative model based on Jones model in order to verify the incidence of earnings management on audit quality. The results attest that the positive relationship between earnings management and audit quality is highly influenced by the accuracy of financial reporting under IFRS. At the same time, the present paper argues a continuous improvement of the financial reporting under audit inspections by Public Interest Oversight Board (PIOBs).
\end{abstract}

Keywords: audit quality, earnings management, financial reporting, globalisation, IFRS, transparency.

\section{Introduction}

One of the first questions of this survey: Is any linkage between earnings management and the quality of audit services? The next question is founded by first answer would be: Does the earnings management influence the degree of transparency in the financial reporting under IFRS?

The audit regulators are represented by the International Forum of Independent Audit Regulators, Financial Reporting Council, Public Interest Oversight Board and Public Company Accounting Oversight Board, which make the assessment concerning the lack of consistency of the audit quality (Knechel et al., 2020). "Public Company Accounting Reform and Investor Protection Act" (2002) or "Corporate and Auditing Accountability, Responsibility, and Transparency Act" has changed totally the audit market by displacing audit self-regulation with audit independent public oversight (Cunningham et al., 2020). The Sarbanes-Oxley Act (2002) represents the key reform that augments the transparency of financial reporting under IFRS and the level of audit services through Public Oversight Boards (POBs) which has the aim to increase the independence of audit profession. The achievement of the audit inspections programs by supervisory bodies (POBs) constitutes the incentives concerning the direct improvement of the relationship between financial audit under ISA and financial reporting under IFRS (Buertey et al., 2020). Auditors provide an expert and independent opinion regarding the accuracy of reporting which has to present true and fair view of financial information regarding the performance and the position of the entity. This reporting will directly influence the public to make well-founded decisions.

DOI: $10.2478 /$ picbe-2021-0073

(C) $2021 \mathrm{M}$. Tache, published by Sciendo.

This work is licensed under the Creative Commons Attribution 4.0 License. 
A study by Houqe (2011) shows that all the features of the client entity can affect the improvement of the information system after adopting IFRS. Also, it was observed that, where the client entities allow a high discretionary power of the manager, no results were seen regarding the quality improvement during the post IFRS period. This discretionary power has raised many problems over time, not always being calculated within the legal limits. When calculating the discretionary power of management, the following must be taken into account: the size of the client entity, the cash flow affected by the operational volatility, the volatility of sales, and the probability of negative earnings. In this context, earnings management was defined as a strategy of the managers to deliberately manipulate the total amount of earnings (Shuli, 2011). Buffett (2009) points out that the managers who make the numbers are tempted to make up the numbers. In other words, the concept earnings management known as "books cooking" describes potential ways of manipulating the financial results.

In order to response to the questions, one OLS regression is computed based on Jones model (1991). Taking as a significant reference in this survey, Carson et al. (2017) argues also the direct effect of audit inspections by POBs on the quality of audit services. The general idea of the linkage between earnings management and the quality of financial reporting is given by the degree of transparency in financial reporting under IFRS. Previous literature has frequently used main accruals as a measurement for earnings management (Healy, 1985; DeAngelo, 1986) or a measure of specific accruals (McNichols and Wilson, 1988).

This survey examines the linkage between earnings management and audit quality taking into consideration the influence of audit inspections and the level of abnormal total accruals, related to the period 2010-2019. More, the sample comprises 14 European countries including United Kingdom with the mention that the collection date ended in 2019. The results of the regression show that the audit inspection decreases the total value of abnormal accrual and the level of financial reporting increases in time. The economic significance of the findings suggests that the audit quality is affected by earnings management which leads to a lower degree of accuracy in financial reporting under IFRS.

The paper is organised as follows: Section II comprises the literature review about financial reporting under IFRS, the quality of audit services and earnings management. Section III outlines the methodology of the research. Section IV corroborates information about the outcome of the OLS regression and the discussions about the final results and Section V draws the conclusions.

\section{Literature review}

IFRSs are the most significant principals issued by the IASB to increase the quality of accounting principles (Chen \& Zhang, 2010) and also globally to standardise them in order to enhance the quality of financial reporting (Tyrrall et al., 2007). Currently, these rules are applied in 175 countries and their number proceeds to grow up in time (Kieso et al., 2020). Statistics argue that the multitude of countries with IFRS adoption is rising because the financial reporting involves a number of advantages, namely: significantly diminishes managerial discretion (In Continental Europe, the accounting system allowed the manipulation of results accounting, efficiency of reflecting financial gains / losses and the use of certain measurement criteria that it effects the economic reality (Lisic et al., 2019).

Financial reporting under IFRS has led to an informational transparency and to a publicly disclosure of financial statements. IFRS' benefits were also notable in the quality of audit services, because more transparent information is reported, and the level of the audit risk is lower. 
Starting with 2002, the independence of audit services is assessed by the audit inspections (Kałdoński et al., 2020). Lamoreux (2016) shows the positive effects of PCAOB inspectors on the quality of audit services as measured by a lower level of earning management. In the same context, Buchholz et al. (2020) points out that the incidence of earnings management affects the financial reporting through different cultural factors.

Kasznik and Lev (1995) argue that the magnitude of earnings is more significant for all the listed companies which predict unfavourable earnings foresight than for the adverse. One study by Aboody and Kasznik (2000) emphasises that managers expedite the procedure to disclose bad news and to prevent the good one to drop the exercise price of the issues. Opposite, the management can withhold the premeditated news predicting that one future event will eliminate the last news (Nagar, 1999). Having the anticipation not to provide bad news and the firm's situation to fix in time, the managers postpone these disclosures (Graham et al., 2005). Further, the stock price conducts the accounting earnings given the circumstance that stock price reverberates the financial flow other than from existing earnings (Brown, 1989). A deeper analysis of earnings management is given by the nature of accruals. Concerning the contractual performance, before the cash flow has been modified, the category of accruals is registered, and possible discretion can rise with respect to the valuation of adequate amount. The main accruals permit recognising in accounting the bad news about future cash flow, having an asymmetrically base. The unaccomplished losses can decrease the actual earnings but can't affect the effective cash flow, while the unaccomplished gains affect neither actual earnings, nor present cash flow. Furthermore, Dechow (1994) shows that through the main accruals, the timeliness of earnings is more significant due to the acknowledgment in time of the bad news. Yang, Chun, Ramadili (2009) point out that effective corporate governance mechanisms should reduce earning management. Liang (2004) motivates that earnings management releases financial information on forecast cash flows, which can augment the quality of the reported information. Therefore, the fair value that outcomes from convergence with IFRS augments the discretionary authority in making one's personal decisions (Hamberg et al., 2011).

The concept of earnings management has the base in the incentives for mangers taking into consideration the linkage between the values of entities, the reported earnings figures and the measurement of discretionary accruals. The presumptions of non-discretions ratio of the total accruals are represented by the discretionary accruals which fall down in the magnitude of errors. All the accruals imply imprecision (Guay et al., 1996) and the potential bias rises from the misclassification between normal and abnormal accruals (Bernard \& Skinner, 1996). The restatement of income accounts which are considered the main core of accounts involves a higher ratio of fraud (Palmrose \& Scholz, 2004). Earnings management is phrased by Schipper (1989) as "a purposeful intervention in the external financial reporting process with the intent of obtaining private gain”.

Taking into consideration the earnings management, one argument for poor quality of the financial reporting under IFRS is based on the non-audit services (NAS) provided by independent auditors. Further, a spoiled auditor independence decreases the wish of auditor to agree client's biases in reported earnings. Frankel et al. (2002) emphasises the positive linkage between the proportion of non-audit fees in the total audit fees with a small portion of earnings management and the magnitude of discretionary accruals. In the scandal between the auditor KPMG and the listed company Xerox Corporation, the Security Exchange Commission (SEC) points out that audit fees are a material incentive for auditors through which the client has the opportunity to handle the earnings (SEC, 2003). In this context, this survey consists evidence about the incidence of earnings 
management on audit quality, taking into consideration the transparency of financial reporting under IFRS. Previous literature (Francis et al., 2013; Carson et al., 2017) attest that the audit quality is measured by the incidence of earnings management through the value of total abnormal accruals. For a better understanding of normal and abnormal components, Jones model (Jones, 1991) and modified Jones model (Dechow et al. 1995) are used as proxies for audit quality and financial reporting under IFRS.

\section{Methodology}

This paper provides evidence that the linkage between earnings management and audit quality is highly influenced by the transparency of financial reporting under IFRS. The approach of the study implies a quantitative research based on Jones model (1991). This model was used in the international financial reporting and auditing literature to estimate the audit quality (Francis et al., 2013). In order to observe the impact of earnings management on audit quality a sample of 5014 observations from 14 countries, in the period 201-2019 was analysed. The model comprises international data and data limitations concerning the englobed fixed effects.

More specific, the following regression is estimated in order to compute the total accruals of the analysed companies:

TAi,t $=\beta 0+\beta 1($ 1/ASSETSsi,t-1 $)+\beta 2(\Delta \mathrm{REVi,t}-\Delta$ ARi,t $)+\beta 3$ PPEi,t $+\beta 4 \mathrm{ROAi}, \mathrm{t}$ + Country / Industry / Year Fixed Effects $+\varepsilon$

Where TAi,t represents total accruals in moment $t$ (determined as the difference between a change in non-cash current assets, a change in current liabilities without the current long-term debt, depreciation and amortisation), scaled by lagged total assets; ASSETSi,t-1 represents total assets in the previous year $\mathrm{t}-1 ; \Delta \mathrm{REVi}, \mathrm{t}$ represents the difference between sales in year $\mathrm{t}$ sales in year

$\mathrm{t}-1 . \Delta \mathrm{ARi}, \mathrm{t}$ represents the difference between accounts receivable in year $\mathrm{t}$ and accounts receivable in year $\mathrm{t}-1$, scaled by lagged total assets; PPEi,t represents net property, plant and equipment in year $\mathrm{t}$, and the last one, ROAi,t represents net income before extraordinary items in year $\mathrm{t}$, scaled by lagged total assets. Chen et al. [2019] points out that the unadjusted abnormal accruals represent the firm-specific residuals.

In the present analysis, the dependent variable is represented by the value of abnormal accruals of incomes. The independent variables are represented by the total value of assets, the dynamics of revenues, accounts receivables, net property, plant and equipment and the net income before extraordinary items. It examines the number of observations for each analysed country, taking into consideration each country-industry-year fixed effects. By including country, industry and year, the variation of abnormal accruals will be more visible (Francis et al. 2013). The effect of unreasonable observations is partially removed by the amounts of the variables presented in the OLS regression [1] which overcome the 1st and 99th percentile (Francis \& Michas, 2013).

\section{Results and discussions}

The quality of audit services and the accuracy of financial reporting under IFRS is given also by the measurement the abnormal total accruals the Jones model (1991) is analysed. Reduced managerial discretion is represented by a lower value of abnormal accruals. World Scope database was used, in order to collect financial data for all the listed companies for 14 European countries. The key variables were total assets, sales, net income and operating income. 
Table 1. Descriptive Statistics of the analysed countries for abnormal and normal total accruals, in the period 2010-2019

\begin{tabular}{|l|l|l|l|}
\hline \multicolumn{1}{|c|}{ Country } & \multicolumn{1}{c|}{ N } & \multicolumn{1}{c|}{ TATA } \\
\hline Austria & 214 & 0,088 & $-0,050$ \\
\hline Belgium & 103 & 0,121 & $-0,062$ \\
\hline Bulgaria & 60 & 0,126 & $-0,022$ \\
\hline Finland & 138 & 0,113 & $-0,054$ \\
\hline France & 142 & 0,113 & $-0,049$ \\
\hline Germany & 84 & 0,122 & $-0,045$ \\
\hline Greece & 46 & 0,099 & $-0,059$ \\
\hline Italy & 46 & 0,100 & $-0,047$ \\
\hline Netherlands & 149 & 0,108 & $-0,063$ \\
\hline Poland & - & 0,185 & $-0,047$ \\
\hline Romania & - & 0,132 & $-0,035$ \\
\hline Spain & 115 & 0,108 & $-0,046$ \\
\hline Sweden & 80 & 0,203 & $-0,060$ \\
\hline United Kingdom & 160 & 0,164 & $-0,082$ \\
\hline
\end{tabular}

Source: Authors' own research results, using STATA program.

Table 1 presents the Descriptive Statistics for every analysed country, the percentage of inspections and the mean of the dependent variable of the total sample, for the period 2010-2019. The following European countries are included in Table 1: Austria, Belgium, Finland, France, Germany, Greece, Italy, Netherlands, Poland, Romania, Spain, Sweden and United Kingdom. For the countries Romania and Bulgaria, the number of inspections is not publicly reported. United Kingdom is part of our sample taking into consideration the time of data collection. Concerning the number of inspections, the average is 111 of inspection yearly. The countries as Austria, United Kingdom, France and The Netherlands has registered the highest number of inspections and Bulgaria, Greece and Italy have recorded the lowest number of inspections.

Table 1, Panel A shows that the mean of the abnormal total accruals is between 0,008 and 0,203 which is very close to those reported in previous literature (Ahmed et al., 2013; Carson et al., 2017). The mean of total accruals is between the value $-0,082$ and the value $-0,022$. For example, Francis et al. (2013) registers the value of $-0,055$ for the mean of total accruals. 
Table 2. Descriptive Statistics of the analysed countries, for abnormal accruals and control variables, in the period 2010-2019

\begin{tabular}{|c|c|c|c|c|c|c|c|c|}
\hline Variables & $\mathbf{N}$ & Mean & Median & $\begin{array}{l}\text { Std. } \\
\text { Dev. }\end{array}$ & Min & $\begin{array}{c}25 \text { th } \\
\text { percentile }\end{array}$ & $\begin{array}{c}\text { 75th } \\
\text { percentile }\end{array}$ & Max \\
\hline $\begin{array}{l}\text { Abnormal Total } \\
\text { Accruals ATA }\end{array}$ & 38.019 & 0,014 & 0,056 & 0,002 & $-0,010$ & 0,023 & 0,111 & 0,674 \\
\hline $\begin{array}{l}\text { Abnormal Total } \\
\text { Accruals - absolute } \\
\text { value } \mid \text { ATA } \mid\end{array}$ & 38.019 & 0,147 & 0,091 & 0,001 & 0,025 & 0,049 & 0,162 & 1,095 \\
\hline $\begin{array}{l}\text { Abnormal Total } \\
\text { Accruals - negative } \\
\text { value neg_ATA }\end{array}$ & 11.339 & $-0,341$ & $-0,118$ & 0,032 & $-0,216$ & $-0,291$ & $-0,040$ & $-2,580$ \\
\hline $\begin{array}{l}\text { Abnormal Total } \\
\text { Accruals - positive } \\
\text { value pos_ATA }\end{array}$ & 26.680 & 0,144 & 0,087 & 0,090 & 0,000 & 0,051 & 0,136 & 0,843 \\
\hline Total Accruals TA & 34.889 & $-0,059$ & $-0,044$ & 1,000 & $-0,008$ & $-0,097$ & $-0,002$ & 0,532 \\
\hline Size & 47.831 & 15,389 & 15,674 & 6,394 & 6,002 & 6,494 & 6,807 & 11,613 \\
\hline $\begin{array}{l}\text { CashFlow from } \\
\text { Operations scaled by } \\
\text { Total Assets }\end{array}$ & 40.601 & $-0,003$ & 0,054 & 0,002 & $-0,006$ & $-0,212$ & 0,112 & 0,496 \\
\hline Growth in Sales & 39.941 & 0,184 & 0,050 & 0,001 & $-0,001$ & $-0,046$ & 0,176 & 6,681 \\
\hline $\begin{array}{l}\text { Growth in Gross } \\
\text { Property, Plant and } \\
\text { Equipment }\end{array}$ & 37.245 & 0,189 & 0,049 & 0,001 & $-0,009$ & 0,000 & 0,153 & 5,542 \\
\hline Leverage ratio & 47.673 & 0,129 & 0,068 & 0,001 & 0,000 & 0,000 & 0,199 & 0,845 \\
\hline $\begin{array}{l}\text { Coefficient of } \\
\text { variation - Sales }\end{array}$ & 46.783 & 0,466 & 0,297 & 0,005 & 0,000 & 0,165 & 0,585 & 2,593 \\
\hline $\begin{array}{l}\text { Coefficient of } \\
\text { variation - Cash Flow } \\
\text { from Operations }\end{array}$ & 47.131 & 0,391 & 0,472 & 0,010 & $-0,198$ & $-0,394$ & 1,023 & 0,209 \\
\hline Sales & 45.240 & 15,329 & 15,675 & 6,808 & 1,161 & 6,449 & 6,808 & 13,888 \\
\hline
\end{tabular}

Table 2, Panel A outlines the Descriptive Statistics for the dependent and control variables of the total sample, for the period 2010-2019. The control variables are the following: Size, Cash Flow from Operations is operating cash flow scaled by total assets, the Growth in Sales represents the percentage of year-to-year growth in sales, the Growth of Gross Property represents a company's one year growth in gross property, plant and equipment from year $t-1$ to year $y$, Plant and Equipment, Leverage ratio is the ratio of term debt to total assets and Sales. Table 2 presents Size and Sales as the natural logarithm of the total value of assets and net sales, respectively. 
Table 3. The effect of earnings management on audit quality, in the period 2010-2019

\begin{tabular}{|c|c|c|c|c|}
\hline Variables & $|\mathbf{A T A}|$ & ATA & ATA negative & ATA positive \\
\hline \multirow[t]{2}{*}{ Num_inspections } & $-0.0221 * * *$ & $-0.0515 * * *$ & $0.0962 *$ & $-0.0311 * * *$ \\
\hline & $(0.00283)$ & $(0.00446)$ & $(0.0514)$ & $(0.00909)$ \\
\hline \multirow[t]{2}{*}{ Size } & $-0.0172 * * *$ & $0.00652 * * *$ & $0.0392 * * *$ & $-0.0167 * * *$ \\
\hline & $(0.00134)$ & $(0.00183)$ & $(0.0132)$ & $(0.00373)$ \\
\hline \multirow[t]{2}{*}{$\mathrm{CFO}$} & $-0.285^{* * *}$ & $0.281 * * *$ & $0.519^{*}$ & $-0.390 * * *$ \\
\hline & $(0.00845)$ & $(0.0144)$ & $(0.281)$ & $(0.0717)$ \\
\hline \multirow[t]{2}{*}{ Growth } & $0.0103 * * *$ & $0.0153 * * *$ & -0.165 & $0.0675^{* * *}$ \\
\hline & $(0.00216)$ & $(0.00328)$ & $(0.141)$ & $(0.0191)$ \\
\hline \multirow[t]{2}{*}{ PPE_Growth } & $0.0197 * * *$ & 0.00149 & $-0.106 * *$ & $0.0218 * *$ \\
\hline & $(0.00233)$ & $(0.00343)$ & $(0.0436)$ & $(0.0105)$ \\
\hline \multirow[t]{2}{*}{ ratio_Leve e } & $0.0345^{* * *}$ & $-0.112 * * *$ & $-0.296^{*}$ & -0.0223 \\
\hline & $(0.00746)$ & $(0.00984)$ & $(0.153)$ & $(0.0207)$ \\
\hline \multirow[t]{2}{*}{ SalesVol } & $0.0759 * * *$ & $-0.0711 * * *$ & 0.0672 & $0.0949 * * *$ \\
\hline & $(0.00449)$ & $(0.00596)$ & $(0.117)$ & $(0.0214)$ \\
\hline \multirow[t]{2}{*}{ CFOVol } & $-0.000769 * * *$ & $0.00109 * * *$ & 0.00294 & $-0.00147 * *$ \\
\hline & $(0.000230)$ & $(0.000329)$ & $(0.00367)$ & $(0.000624)$ \\
\hline \multirow[t]{2}{*}{ Sales } & $0.00545^{* * *}$ & $0.00774 * * *$ & 0.0148 & $0.0103 * * *$ \\
\hline & $(0.00125)$ & $(0.00179)$ & $(0.0331)$ & $(0.00353)$ \\
\hline \multirow[t]{2}{*}{ Constant } & $0.198 * * *$ & $0.0432 * * *$ & $-0.432 * * *$ & $0.180 * * *$ \\
\hline & $(0.00825)$ & $(0.00939)$ & $(0.0756)$ & $(0.0157)$ \\
\hline Observations & 34,713 & 34,713 & 10,057 & 24,656 \\
\hline [Pseudo] R-squared & 0.295 & 0.185 & 0.020 & 0.079 \\
\hline Industry Fixed Effects & Yes & Yes & Yes & Yes \\
\hline Year Fixed Effects & Yes & Yes & Yes & Yes \\
\hline
\end{tabular}

PICBE | 789 


\begin{tabular}{|l|l|l|l|l|}
\hline \multicolumn{1}{|c|}{ Variables } & \multicolumn{1}{|c|}{ |ATA| } & \multicolumn{1}{|c|}{ ATA } & \multicolumn{1}{c|}{ ATA negative } & \multicolumn{1}{c|}{ ATA positive } \\
\hline Country Fixed Effects & Yes & Yes & Yes & Yes \\
\hline Standard Error & Cluster IYC & Cluster IYC & Cluster IYC & Cluster IYC \\
\hline
\end{tabular}

PICBE |

Source: Authors' own research results, using STATA program.

The results of earnings management on audit quality are presented in Column (1) as the absolute value of the abnormal total accruals. All models are significant at $p$-value $<0,01$ with $R$ squared lower than $30 \%$. Using OLS regression, the results attest a significant positive coefficient for the number of inspections which implies that the level of earnings management decreases in time. The analysis is repeated in order to compute the negative and positive value of the abnormal total accrual. The result is significant for less income-increasing total accruals ( $\mathrm{p}$-value $<0,01)$ and less income-decreasing total accruals ( $\mathrm{p}$-value $<0,01)$ presuming that the audits restrict upward and downward earnings management. More, the accuracy of financial reporting under IFRS and a lower level of recorded earnings management arguments the audit quality. All the control variables are significant associated with the total value of abnormal total accruals, except for the growth of Cash Flow from Operations.

\section{Conclusion}

The direct influence of earnings management affects the quality of audit services, and at the same time the quality of financial reporting under IFRS. One key factor for earnings management is represented by the total value of abnormal accruals. Reduced managerial discretion is represented by a lower value of abnormal accruals.

This paper comprises an analysis of 14 European countries, based on Jones model, for the period 2010-2019 in order to observe the incidence of earnings management on audit services. One OLS regression was computed to verify the inference of discretionary accruals in the transparency of financial reporting. As it is showed by Carson et al. (2017) the impact of audit inspections has considerable changes in the quality of audit services. As its outcomes from this similar research, the audit inspection by supervisory bodies (PIOBs) diminishes considerable the level of earnings management and consequently the transparency of financial reporting under IFRS. The economic significance of the number of audit inspections by PIOBs attests that the introduction of audit inspections leads to a decrease of the absolute value of abnormal total accruals, and consequently to a lower level of earnings management.

Thus, the answer of the two questions that started the current research is sustained by computing the influence of audit inspection through Jones model (1991). The findings strengthen previous literature (Carson et al., 2017) even in the actual circumstances.

\section{References}

Aboody, D., \& Kasznik, R. (2000). CEO stock option awards and the timing of corporate voluntary disclosures, Journal of accounting and economics, 29(1), 73-100.

Ahmed, K., Chalmers, K., \& Khlif, H. (2013). A meta-analysis of IFRS adoption effects, The International Journal of Accounting, 48(2), 173-217. 
Bernard, V. L., \& Skinner, D. J. (1996). What motivates managers' choice of discretionary accruals?, Journal of Accounting and Economics, 22(1-3), 313-325.

Brown, P. (1989). Invited Remarks: Ball and Brown (1968), Journal of Accounting Research, 27, 202-217.

Buchholz, F., Lopatta, K., \& Maas, K. (2020). The deliberate engagement of narcissistic CEOs in earnings management, Journal of Business Ethics, 167(4), 663-686.

Buertey, S., Sun, E. J., Lee, J. S., \& Hwang, J. (2020). Corporate social responsibility and earnings management: The moderating effect of corporate governance mechanisms. Corporate Social Responsibility and Environmental Management, 27(1), 256-271.

Buffett, W. (2009). Warren Buffett on business: Principles from the sage of Omaha, John Wiley \& Sons.

Carson, E., Simnett, R., Thuerheimer, U., \& Vanstraelen, A. (2017). The effect of national inspection regimes on audit quality, Available at SSRN 3049828.

Chen, J. J., \& Zhang, H. (2010). The impact of regulatory enforcement and audit upon IFRS compliance - Evidence from China, European Accounting Review, 19(4), 665-692.

Chen, H., Hua, S., Liu, Z., \& Zhang, M. (2019). Audit fees, perceived audit risk, and the financial crisis of 2008.

Cunningham, L. M., Johnson, B. A., Johnson, E. S., \& Lisic, L. L. (2020). The switch-up: An examination of changes in earnings management after receiving SEC comment letters, Contemporary Accounting Research, 37(2), 917-944.

DeAngelo, L. E. (1986). Accounting numbers as market valuation substitutes: A study of management buyouts of public stockholders, Accounting review, 400-420.

Dechow, P. M. (1994). Accounting earnings and cash flows as measures of firm performance: The role of accounting accruals. Journal of accounting and economics, 18(1), 3-42.

Dechow, P. M., Sloan, R. G., \& Sweeney, A. P. (1995). Detecting earnings management, Accounting review, 193-225.

Elliott, R. K., \& Jacobson, P. D. (2002). The evolution of the knowledge professional, Accounting Horizons, 16(1), 69-80.

Francis, J. R., \& Michas, P. N. (2013). The contagion effect of low-quality audits, The Accounting Review, 88(2), 521-552.

Francis, J. R., Michas, P. N., \& Seavey, S. E. (2013). Does audit market concentration harm the quality of audited earnings? Evidence from audit markets in 42 countries, Contemporary Accounting Research, 30(1), 325-355.

Frankel, R. M., Johnson, M. F., \& Nelson, K. K. (2002). The relation between auditors' fees for non-audit services and earnings management. The accounting review, 77(s-1), 71-105.

Graham, J. R., Harvey, C. R., \& Rajgopal, S. (2005). The economic implications of corporate financial reporting, Journal of accounting and economics, 40(1-3), 3-73.

Guay, W. R., Kothari, S. P., \& Watts, R. L. (1996). A market-based evaluation of discretionary accrual models, Journal of accounting research, 34, 83-105.

Hamberg, M., Paananen, M., \& Novak, J. (2011). The adoption of IFRS 3: The effects of managerial discretion and stock market reactions, European Accounting Review, 20(2), 263-288.

Healy, P. M. (1985). The effect of bonus schemes on accounting decisions, Journal of accounting and economics, 7(1-3), 85-107.

Healy, P. M., \& Wahlen, J. M. (1999). A review of the earnings management literature and its implications for standard setting, Accounting horizons, 13(4), 365-383. 
Houqe, M. N. (2017). IFRS Adoption and Audit Fees-Evidence from New Zealand, International Journal of Business \& Economics, 16(1).

Jones, J. J. (1991). Earnings management during import relief investigations, Journal of accounting research, 29(2), 193-228.

Kałdoński, M., Jewartowski, T., \& Mizerka, J. (2020). Capital market pressure, real earnings management, and institutional ownership stability-Evidence from Poland, International Review of Financial Analysis, 71.

Kasznik, R., \& Lev, B. (1995). To warn or not to warn: Management disclosures in the face of an earnings surprise, Accounting review, 113-134.

Kieso, D. E., Weygandt, J. J., \& Warfield, T. D. (2020). Intermediate accounting IFRS, John Wiley \& Sons.

Kinney Jr, W. R., Palmrose, Z. V., \& Scholz, S. (2004). Auditor independence, non-audit services, and restatements: Was the US government right?, Journal of Accounting Research, 42(3), 561-588.

Knechel, W. R., \& Vanstraelen, A. (2007). The relationship between auditor tenure and audit quality implied by going concern opinions, Auditing: A journal of practice \& theory, 26(1), 113-131.

Knechel, W. R., Thomas, E., \& Driskill, M. (2020). Understanding financial auditing from a service perspective. Accounting, Organizations and Society, 81, 101080.

Li, Y., Roge, J. N., Rydl, L., \& Hughes, J. (2007). Achieving Sarbanes-Oxley compliance with XBRL-based ERP and continuous auditing, Issues in Information Systems, 8(2), 430-436.

Liang, P. J. (2004). Equilibrium earnings management, incentive contracts, and accounting standards. Contemporary Accounting Research, 21(3), 685-718.

Lisic, L. L., Myers, L. A., Pawlewicz, R., \& Seidel, T. A. (2019). Do accounting firm consulting revenues affect audit quality? Evidence from the pre-and post-SOX eras, Contemporary Accounting Research, 36(2), 1028-1054.

McNichols, M., \& Wilson, G. P. (1988). Evidence of earnings management from the provision for bad debts, Journal of accounting research, 1-31.

Nagar, V., Nanda, D., \& Wysocki, P. (2003). Discretionary disclosure and stock-based incentives, Journal of accounting and economics, 34(1-3), 283-309.

Palmrose, Z. V., Richardson, V. J., \& Scholz, S. (2004). Determinants of market reactions to restatement announcements. Journal of accounting and economics, 37(1), 59-89.

Schipper, K. (1989). Earnings management, Accounting horizons, 3(4), 91.

Shuli, I. (2011). Earnings management and the quality of the financial reporting, Perspectives of Innovations, Economics and Business, PIEB, 8(2), 45-48.

Tyrrall, D., Woodward, D., \& Rakhimbekova, A. (2007). The relevance of International Financial Reporting Standards to a developing country: Evidence from Kazakhstan, The international Journal of accounting, 42(1), 82-110.

Yang, W. S., Chun, L. S., \& Ramadili, S. M. (2009). The effect of board structure and institutional ownership structure on earnings management, International Journal of Economics and Management, 3(2), 332-353.

https://www.afm.nl/en/nieuws/2019/nov/rapport-kwaliteit-overige-oob-accountants.

https://pcaobus.org/About/Administration/Documents/Strategic\%20Plans/2017-2021.pdf.

https://www.ifiar.org/?wpdmdl=10453.

https://www.frc.org.uk/getattachment/5e1ac2d1-f58c-48bc-bb91-1f4a189df18b/Developmentsin-Audit-2018.pdf.

DOI: $10.2478 /$ picbe-2021-0073, pp. 783-792, ISSN 2558-9652

Proceedings of the $15^{\text {th }}$ International Conference on Business Excellence 2021 